\title{
Covid-19: Bolsonaro under fire as Brazil hides figures
}

\section{Owen Dyer \\ Montreal, Canada}

Brazilians may no longer see their cumulative totals of cases and deaths on the government's covid-19 web dashboard, after the country's far right president Jair Bolsonaro ordered the data to be removed. Only the daily new cases and deaths are now visible. $^{1}$

Bolsonaro "freaked out" as the number of deaths appeared set to pass the UK's figure, anonymous health officials told the newspaper Correio Braziliense. This would leave Brazil second in the world for total covid-19 deaths, behind only the US. Brazil currently has 710887 cases and 37312 deaths.

The president also plans to misrepresent the numbers, health officials warned, by reclassifying covid-19 deaths under other causes. The new secretary of science and technology at the health ministry, billionaire Mormon businessman Carlos Wizard, claimed the current figures are inflated by "public managers purely interested in having bigger budgets."

"We are revising these obits," he told the $O$ Globo newspaper. In fact, experts agree that Brazil's official figures already understate the true impact.

Wizard is part of a new team at the health ministry, one lacking medical experience and led by a general—Brazil's third health minister of the pandemic.

Bolsonaro fired health minister Luiz Henrique Mandetta in April after they disagreed on social distancing measures. A second health minister resigned with no explanation after a month in the job. Bolsonaro has consistently played down the risk, calling covid-19 "a little flu" and has ostentatiously refused to take precautions himself.

Last week, the president moved the televised daily briefing from the $7 \mathrm{pm}$ slot to $10 \mathrm{pm}$, partly, he said, in hopes of harming the ratings of an evening news programme he dislikes.
The UK government drew criticism for dropping international comparison charts from the Downing Street daily briefing just as England's covid-19 mortality threatened to become the worst in Europe.

Bolsonaro's public approval has plunged during the pandemic. His latest move drew condemnation from across society and vows that deaths would not go unrecorded.

"Manipulation, omission, and disrespect are the marks of authoritarian administrations," Paulo Câmara, governor of Pernambuco, posted on Instagram. "But this won't destroy the effort of the whole nation. We will continue producing, systematising, and releasing the data."

Gilmar Mendes, minister of the supreme court, tweeted, "The manipulation of statistics is a manoeuvre of totalitarian regimes. The trick will not exempt responsibility for the eventual genocide."

A statement from Alberto Beltrame, president of Brazil's national council of state health secretaries, said, "The authoritarian, insensitive, inhuman, and unethical attempt to make those killed by covid-19 invisible will not succeed. We and Brazilian society will not forget them, nor the tragedy that befalls the nation."

1 Brazil Ministry of Health. Covid-19: cronavirus panel. https://covid.saude.gov.br. This article is made freely available for use in accordance with BMJ's website terms and conditions for the duration of the covid-19 pandemic or until otherwise determined by BMJ. You may use, download and print the article for any lawful, non-commercial purpose (including text and data mining) provided that all copyright notices and trade marks are retained.

https://bmj.com/coronavirus/usage 